\title{
PERANAN PEMBELAJARAN KEWIRAUSAHAAN DALAM MEMBENTUK KARAKTER ISLAMI PADA MAHASISWA UIN SUSKA RIAU
}

\author{
Oleh : Akmal, Naskah \\ Universitas Islam Negeri Sultan Syarif Kasim Riau \\ E-mail : akmal@gmail.suska.ac.id, : naskah20@gmail.com
}

\begin{abstract}
Penelitian bertujuan untuk mengetahui Peranan pembelajaran Kewirausahaan dalam membentuk karakter yang islami pada mahasiswa Program Studi Pendidikan Ekonomi UIN Suska Riau. Metode penelitian adalah metode kualitatif. Jenis data adalah data primer yaitu melaui wawancara, observasi, kuisioner. Koresponden yaitu mahasiswa di Program Studi Pendidikan ekonomi UIN Suska Riau. Hasil analisis tersebut dapat disimpulkan bahwa: 1. Pemahaman Mahasiswa Tentang Kewirausahaan yaitu (a) mahasiswa memahami konsep kewirausahaan sebesar (97,90\%) diantaranya tahu tentang Kewirausahaan (Entrepreneurship); (b) mahasiswa pernah melaksanakan kegiatan kewirausahaan (Entrepreneurship) sebanyak (97,48\%) (c) mahasiswa mengatakan mengetahui tentang Islam meganjurkan untuk berwirausahaan (Entrepreneurship) $(74,37 \%)$; 2. Karakter Islami dalam kewirausahaan (Entrepreneurship) yang Terbentuk yaitu (a) Diperoleh sebanyak $(85,72 \%)$ sudah terbentuk karakter kerja keras; (b) Diperoleh sebanyak (80,25\%) sudah terbentuk karakter Adil ('adilun) ; (c) Diperoleh sebanyak (84,04\%) sudah terbentuk karakter Percaya (amanah); (d) Diperoleh sebanyak (73,53\%) sudah terbentuk karakter Jujur; (f) Diperoleh sebanyak (73,95\%) sudah terbentuk karakter Tanggung Jawab; (g) Diperoleh sebanyak $(68,06 \%)$ sudah terbentuk Karakter Mandiri.
\end{abstract}

Kata kunci : Pembelajaran Kewirausahaan, Karakter yang islami

\begin{abstract}
This study aims to determine the role of entrepreneurial learning in shaping the Islamic character of the students majoring in study program Economic education UIN Suska Riau. Method or approach used in this research is by using qualitative method. The type of data to be used in this study is primary data that is data directly obtained from the field through interviews, observations, questionnaires. Correspondent is the students in the college program of economic education UIN Suska Riau. And the results of the analysis can be concluded that: 1. Understanding Economics Students About Entrepreneurship is (a) understand the concept of entrepreneurship. This is evidenced (97.90\%) of them know about Entrepreneurship (Entrepreneurship); (b) conducted entrepreneurship activities (Entrepreneurship) (97.48\%) ; (c) most of the students said that they know about Islam promises to entrepreneurship (Entrepreneurship) (74.37\%); 2. Islamic Character in Entrepreneurship (Entrepreneurship) Formed (a) Obtained (85.72\%) has formed the character of hard work; (b) Retrieved (80.25\%) have already formed the character of Fair ('fairun) ; (c) Obtained (84.04\%) have formed the character of Trust (trust); (d) Acquired $(73.53 \%)$ have been formed Honest character; $(f)$ Obtained (73.95\%) have been formed character Responsibility; $(g)$ Retrieved (68.06\%) have been formed Independent Character.
\end{abstract}

Keywords: Entrepreneurship Learning, Islamic Character 


\section{LATAR BELAKANG}

Pembelajaran merupakan proses atau kegiatan membelajarkan siswa dalam mempelajari perilaku manusia dalam memilih dan menciptakan kemakmuran. Pembelajaran hendaknya hadir sebagai menjawab kebutuhan pendidikan yang lebih mengacu pada sumber daya manusia yang siap pakai, mempunyai kompetensi yang handal. Maka dari itu, tujuan tersebut diimplementasikan dalam bentuk standar kurikulum, di samping penerapan konsep pendidikan yang ditanamkan mengenai kecakapan afektif, kognitif, dan psikomotorik. Dalam Standar kompetensi lulusan pada satuan pendidikan bertujuan untuk meningkatkan kecerdasan, pengetahuan, kepribadian, ahklak mulia, serta keterampilan untuk hidup mandiri dan mengikuti pendidikan lebih lanjut sesuai dengan kejuruannya.

Sasaran dalam pembelajaran kewirausahaan adalah untuk mempersiapkan mahasiswa sebagai calon tenaga kerja yang memiliki kesiapan untuk memasuki dunia kerja. Keberadaan mahasiswa dituntut untuk memenuhi kebutuhan masyarakat, yaitu kebutuhan tenaga kerja. Sehingga mahasiswa dituntut untuk memiliki keterampilan serta sikap professional dalam bidangnya.
Saat ini persaingan dalam dunia kerja sangatlah ketat, penyerapan tenaga kerja dalam dunia usaha dan industri serta perekrutan pegawai negeri sangatlah terbatas dan dengan tingkat kompetensi yang tinggi. Sementara itu semakin banyaknya perusahaan melakukan Pemutusan Hubungan Kerja (PHK), sehingga membuat persaingan di antara lulusan perguruan tinggi dalam mendapatkan pekerjaan semakin ketat. Mengandalkan kepada pemerintah untuk membuka lapangan kerja baru tidaklah mungkin. Menunggu investor dari luar negeri untuk berinvestasi ke Indonesia memerlukan waktu yang cukup lama, dan mengharapkan investor dari dalam negeri dalam kondisi saat seperti ini sangatlah berat. Melihat kondisi tersebut di atas, maka dunia pendidikan harus mampu berperan aktif menyiapkan sumber daya manusia terdidik yang mampu menghadapi berbagai tantangan kehidupan lokal, nasional, regional maupun internasional yang tidak hanya menguasai teori tapi juga mampu menerapkan dalam kehidupan sosial dan yang kreatif yang mampu menciptakan lapangan pekerjaan untuk dirinya sendiri dan orang lain atau seorang wirausaha. 
Terwujudnya suatu pembangunan yang mengarah kepada para wirausahawan diharapkan dapat meningkatkan pertumbuhan ekonomi yang pada gilirannya dapat menyerap tenaga kerja baru. Daya serap pertumbuhan ekonomi Indonesia diharapkan meningkat dua kali lipat agar jumlah lapangan kerja baru yang tersedia bertambah dan angkatan kerja baru mendapatkan pekerjaan. Ini diperlukan karena pertumbuhan ekonomi yang ada sekarang belum mampu menyediakan lapangan kerja baru bagi para pengangguran.

Salah satu solusi dari permasalahan ini adalah dengan menumbuhkan wirausahawan-wirausahawan dari penduduk Indonesia yang tidak hanya mempunyai modal tetapi juga mampu untuk berinovasi, sehingga dapat mengolah bahan baku sehingga menciptakan produk baru yang dapat bersaing dengan produkproduk asing. Penumbuhan wirausahawan yang inovatif bermula dari pendidikan yang diajarkan dalam lembaga pendidikan. Lembaga pendidikan di Indonesia harus mampu memberikan pemahaman mengenai kewirausahaan tidak hanya berupa teori melainkan lebih banyak untuk berkarya dan mencipta, sehingga dari sanalah tangan-tangan muda akan terlatih untuk selalu berkarya dan mencipta untuk kemajuan bangsanya.

Kualitas pendidikan harus terus menerus ditingkatkan. Kualitas pendidikan terkait dengan kualitas kreatif dan inovatif. Kualitas kreatif dan inovatif dapat dicapai apabila proses pembelajaran berlangsung secara efektif dan peserta didik dapat menghayati dan menjalani proses pembelajaran tersebut secara bermakna. Proses kreatif dan inovatif hanya dapat dilakukan oleh orang-orang yang memiliki sikap kewirausahaan. Yakni orang-orang yang percaya diri, berinisiatif, memiliki motif berprestasi, berwawasan kedepan, memiliki jiwa kepemimpinan dan berani mengambil resiko dengan penuh perhitungan. Dengan demikian untuk mencapai kemampuan di atas perlu dikembangkan model pendidikan kewirausahaan yang mampu menumbuhkan karakter dan perilaku wirausaha pada peserta didik.

Dunia pendidikan memiliki tugas yang tidak ringan dalam menghadapi era globalisasi sekarang ini, pendidikan adalah masalah yang sangat penting terlebih lagi dalam lajunya pembangunan nasional yang dituntut adanya generasi yang lebih maju disamping mempersiapkan peserta didik untuk meningkatkan ilmu pengetahuan dan 
teknologi (iptek) diharapkan juga mampu meningkatkan keimanan ketakwaan (imtak) terhadap Tuhan Yang Maha Esa, peningkatan keimanan dan ketakwaan dilakukan untuk mengantisipasi dampak negatif dari perkembangan ilmu pengetahuan dan teknologi pada masa sekarang ini. Dhikrul Hakim (2008:1).

Pada pembelajaran kewirausahaan ada nilai-nilai entrepreneurship yang perlu diketahui dan dimengerti yang bisa diinternalisasikan dalam diri peserta didik pada proses pembelajaran. Nilai-nilai tersebut yaitu: mandiri, kreatif, berani mengambil resiko, berorientasi pada tindakan, kepemimpinan, kerja keras, jujur, disiplin, inovatif, tanggung jawab, kerjasama, pantang menyerah, komitmen, realistis, rasa ingin tahu, komunikatif, dan motivasi kuat untuk sukses (Kemendiknas, 2010: 10-11).

Pada saat ini Kewirausahaan (entrepreneurship) menjadi tema besar yang menarik untuk diperbincangkan, bukan saja dalam ranah ekonomi, melainkan pada setiap ranah kehidupan; sosial, kesehatan, politik, pemerintahan, bahkan pendidikan. Untuk perbincangan pada ranah terakhir, tentunya entrepreneurship akan bersinggungan dengan sub-sub tema yang antara lain berkaitan dengan pendidik, peserta didik, proses pembelajaran, dan hasil pembelajaran. Dengan kata lain, tema pendidikan adalah tema yang berkaitan dengan peran pendidik yang membantu peserta didiknya agar bakat dan potensinya berkembang optimal, sehingga lahir sumber daya manusia menjadi lebih baik.

Pembelajaran mempunyai peluang yang cukup besar untuk ikut serta dalam membangun sistem perekonomian dengan memanfaatkan tahap perkembangan mahasiswa, mendidik mahasiswa agar berminat menjadi wirausaha. Pendidikan yang dimaksud adalah pendidikan yang berorientasi pada pembentukan jiwa entrepreneurship yaitu jiwa keberanian dan mandiri yang tidak bergantung kepada siapapun. Pembelajaran kewirausahaan pada dasarnya bertujuan mengembangkan keterampilan, kemampuan, sikap kebiasaan kerja dan pengetahuan bagi calon pekerja guna memenuhi dan mengembangkan keterampilan kerja agar mampu menjadi pekerja yang betul-betul berguna dan produktif. Namun Pembelajaran kewirausahaan juga harus mampu berperan dalam mempersiapkan mahasiswa yang mampu bertindak, belajar dan mengatur masa depannya secara aktif dan mandiri dimana tidak bergantung kepada 
pemerintah atau swasta, mereka mempunyai minat yang tinggi untuk dapat menciptakan lapangan pekerjaan sendiri atau berwirausaha.

Kewirausahaan (entrepreneurship) yang dijadikan sebagai salah satu kompetensi yang harus dicapai dalam Standar Kompetensi Lulusan, telah teruji mengandung nilai-nilai kebaikan yang sepatutnya dimiliki peserta didik. Nilainilai kebaikan yang terkandung yaitu mempunyai visi dan misi, kreatif dan inovatif, berani menanggung resiko, berjiwa kompetisi, mampu melihat dan menciptakan peluang, cepat tanggap dan gerak cepat, berjiwa sosial dan menjadi dermawan (Gina, 2009: 5).

Islam memang tidak memberikan penjelasan secara eksplisit terkait konsep tentang kewirausahaan (entrepreneurship) ini, namun di antara keduanya mempunyai kaitan yang cukup erat, memiliki ruh atau jiwa yang sangat dekat, meskipun bahasa teknis yang digunakan berbeda.

Islam sangat menganjurkan umatnya untuk melakukan wirausaha. Banyak ditemukan ayat atau hadits yang mendorong umat Islam untuk berwirausaha, misalnya keutamaan berdagang seperti disebutkan dalam hadits yang artinya: "Perhatikan olehmu sekalian perdagangan, dengan tangannya sendiri dan setiap jual beli yang bersih."(HR. Al Bazzar). Dalam Al-quran menyebutkan, "..apabila shalat telah ditunaikan maka bertebaranlah kamu di muka bumi dan carilah karunia (rizki) Allah" (QS. alJumu'ah: 10).

Kewirausahaan dan Perdagangan dalam pandangan islam merupakan aspek kehidupan yang dikelompokkan kedalam masalah mu'amalah, yaitu masalah yang berkenaan dengan hubungan yang bersifat horizontal antar manusia dan tetap akan di pertanggungjawabkan kelak di akhirat. Manusia diperintahkan untuk memakmurkan bumi dan membawanya ke arah yang lebih baik serta diperintahkan untuk berusaha mencari rizki. Semangat kewirausahaan diantaranya terdapat dalam QS. Al-Baqarah: 275, QS.Al-Mulk:15 dan QS.Al-Jumuh:10, dimana manusia diperintahkan untuk memakmurkan bumi dan membawanya ke arah yang lebih baik serta diperintahkan untuk berusaha mencari rizki.

Semangat kewirausahaan terdapat dalam Al-Qur'an yang akan di uraikan sebagai berikut, QS. Al-Baqarah: 275 yang artinya :“...Allah telah menghalalkan jual beli dan mengharamkan riba". QS.Al-Mulk:15, yang artinya : "Dialah 
Yang menjadikan bumi itu mudah bagi kamu, maka berjalanlah di segala penjurunya dan makanlah sebahagian dari rezeki- Nya. Dan hanya kepada-Nya-lah kamu (kembali setelah) dibangkitkan". QS. Al-Jummuah 10 yang artinya : "Apabila telah ditunaikan shalat, maka bertebaranlah kamu di muka bumi; dan carilah karunia Allah dan ingatlah Allah banyak-banyak supaya kamu beruntung."

Konsep kewirausahaan telah diajarkan oleh Nabi Muhammad SAW, jauh sebelum beliau menjadi Rasul. Rosulullah telah memulai bisnis kecil-kecilan pada usia kurang dari 12 tahun dengan cara membeli barang dari suatu pasar, kemudian menjualnya kepada orang lain untuk mendapatkan keuntungan agar dapat meringankan beban pamannya. Bersama pamannya, Rosulullah melakukan perjalanan dagang ke Syiria. Bisnis Rosulullah terus berkembang sampai kemudian Khadijah menawarkan kemitraan bisnis dengan sistem profit sharing. Selama bermitra dengan Khadijah, Rosulullah telah melakukan perjalanan ke pusat bisnis di Perjalanan bisnis Rosulullah selama bertahun-tahun memberikan hikmah tentang bagaimana unsur-unsur manajemen usaha Rosulullah SAW. Bahkan dalam aktifitas penggembalaan kambing yang dilakukan oleh Rosulullah terdapat nilai-nilai luhur yang terkandung yaitu: pendidikan rohani, latihan merasakan kasih sayang kepada kaum lemah, serta kemampuan mengendalikan pekerjaan berat dan besar. Trim (2009) mengungkapkan bahwa kredibilitas dan kapabilitas Nabi Muhammad SAW terdapat dalam empat karakter unggulnya, yaitu FAST (Fathonah, Amanah, Shiddiq dan Tabligh) ditambah faktor I, yaitu Istiqomah. Sifat Fathonah (cerdas) dalam diri Nabi Muhammad SAW adalah seorang jenius dengan bukti kepakaran sebagai 1) ahli politik; 2) ahli strategi peran; 3) ahli diplomasi; 4) ahli hubungan antar kaum; 5) ahli strategi; 6) negarawan; 7) pengambil keputusan; 8) ahli perlembagaan; 9) ahli pembangunan SDM; 10) ahli pembangunan masyarakat; 11) ahli tata keluarga; 12) ahli dakwah (Archivo, 2014: 2 ).

Sifat amanah (komitmen) tercermin dalam sikap Rosulullah yang senantiasa menggunakan akad, kesepakatan atau perjanjian bisnis dengan sistem kesepakatan bersama. Seseorang dianggap melalaikan komitmen apabila 
tidak melaksanakan hal-hal yang telah disepakati bersama. Rosulullah SAW bersabda : "Allah Azza wa jalla berfirman: "Aku adalah pihak ketiga dari kedua belah pihak yang berserikat selama salah seorang dari keduanya tidak mengkhianati temannya. Jika salah satu dari keduanya telah mengkhianati temannya, Aku terlepas dari keduanya." (HR Abu Dawud).

Sifat Shiddiq (benar dan jujur) dapat tercermin dari beberapa sikap Rosulullah. Pertama, Rosulullah bersikap baik dan jujur kepada perusahaan atau pemegang saham. Terbukti, setelah membantu bisnis pamannya, Rosulullah mampu mengelola bisnis Khadijah ra dengan baik. Kedua, Rosulullah bersikap baik dan jujur kepada pegawai. Rosulullah pernah menasehati untuk membayar upah seorang pegawai sebelum keringatnya kering. Hal tersebut menunjukkan bahwa perusahaan tidak boleh menunda-nunda hak seorang pegawai apabila perusahaan sedang tidak mengalami kesulitan untuk membayar gaji tersebut.

Sifat Tabligh (Komunikatif). Sifat Rosulullah untuk senantiasa bersikap tabligh sejalan dengan firman Allah SWT dalam QS. An-Nisa ayat 9 yaitu : oleh karena itu, hendaklah mereka bertakwa kepada Allah SWT dan hendaklah mereka mengucapkan perkataan yang benar". Terakhir adalah sifat Istiqomah (keteguhan hati yang konsisten). Rosulullah senantiasa istiqomah dalam menjalankan nilai-nilai bisnis Islam (FAST) untuk dapat menjaga kepercayaan bisnis dari orang lain.

Seorang wirausaha harus selektif dalam memilih suatu kegiatan usaha ataupun suatu pekerjaan, dan menumbuhkan etos kerja yang Islami menjadi suatu keharusan. Tanpa itu, seorang wirausaha hanya bisa mendapat nilai materi yang secara kuantitas yang hanya menjanjikan kepuasan semu. Padahal nilai spiritual yang berkualitas berupa "berkah" sangat penting untuk kehidupan, bahkan lebih penting dari segala-segalanya. Agar kita terhindar dari hal-hal tersebut di atas, maka kita perlu menumbuhkan etos kerja secara Islami. Adapun etos kerja tersebut adalah:

a) Niat ikhlas karena Allah semata Islam menetapkan betapa pentingnya keikhlasan niat dan perilaku dalam setiap langkah kehidupan. Karena nilai pekerjaan kita bisa menjadi ibadah atau tidak sangat bergantung pada niat 
untuk apa kita melaksanakan sesuatu. Niat hanya karena Allah, akan menyadarkan kita bahwa: sesungguhnya Allah SWT, memantau segala aktifitas yang kita kerjakan, segala yang kita peroleh wajib disyukuri, rezeki harus digunakan dan dibelanjakan pada jalan yang benar, dan menyadari apa saja yang kita peroleh pasti ada pertanggungjawaban kepada Allah SWT. Kode etik tersebut mengakibatkan kerja lebih efisien juga tingkat produktifitas lebih tinggi. Keikhlasan juga mengurangi manipulasi atau eksploitasi orang lain untuk alasan-alasan individu. Kesadaran- kesadaran di atas akan terus membimbing kita, sekaligus mencegah perbuatan curang dan culas dalam mencari rezeki.

b) Kerja keras (al-jiddu fi al- 'amal) Orang sering menghalalkan segala cara agar cepat menjadi kaya, karena sudah tidak tahan merasakan kemiskinan. Islam memerintahkan kita agar bekerja keras. Maksudnya, bekerja dengan sungguh-sungguh, sepenuh hati, jujur dan mencari rezeki yang halal dengan cara-cara yang halal pula. Karena yang demikian itu dapat dikategorikan sebagai perbuatan ibadah (jihad). Orang yang bekerja keras dikelompokkan sebagai mujahid di jalan Allah selama sesuai dengan ketentuan syariat Islam dan motivasi utama dia bekerja keras adalah karena melaksanakan perintah Allah SWT dan Rasul-Nya.

c) Memiliki cita-cita yang tinggi (al-himmah al- 'aliyah)

Manusia jangan puas hanya menjadi bawahan seumur hidup, manusia harus berusaha menjadi pemilik usaha untuk masa-masa tertentu. Kalau sekarang kita ke sana-kemari mencari pekerjaan, tetapi di suatu masa nanti kita akan membuka dan memberi peluang orang lain bekerja di tempat kita. Inilah cita-cita yang tinggi untuk ditanamkan dalam benak kita sejak awal mulai bekerja. Semua manusia mempunyai potensi dan peluang yang sama untuk keluar sebagai pemenang.

Kewirausahaan dalam Islam merupakan segala kegiatan/aktifitas yang dilakukan manusia untuk memenuhi kebutuhan hidupnya dalam berbagai bentuk yang tidak dibatasi jumlah (kuantitas) kepemilikan harta (barang/jasa) termasuk profitnya, namun dibatasi dalam cara perolehan dan pendayagunaan hartanya (ada aturan halal dan haram). Seorang muslim yang profesional haruslah memiliki sifat amanah, yakni terpercaya dan bertanggung jawab. Sikap amanah mutlak harus dimiliki 
seorang wirausaha muslim, agar terhindar dari tindakan yang merugikan orang lain. Sikap amanah bisa dimiliki jika kita selalu menyadari bahwa apa pun aktifitas yang kita lakukan (termasuk pada saat bekerja) selalu diketahui oleh Allah SWT.

Sikap amanah juga merupakan refleksi dari akhlak mulia sehingga merupakan sesuatu yang semestinya menjadi pakaian orang-orang yang beriman. Sebab, dengan sifat amanah, seseorang akan merasa tenang dan aman untuk berhubungan, berinteraksi, dan bermuamalah dalam mengisi kehidupan. Ada banyak faktor mengapa orang terdorong bersikap tidak amanah. Salah satunya adalah keinginan untuk mendapatkan keuntungan finansial (kekayaan) melalui cara-cara yang culas (suap, korupsi, kolusi, manipulasi, dan sebagainya). Memang sangat mungkin diperoleh keuntungan finansial yang luar biasa. Dengan kata lain, ia secara sadar akan berusaha keras agar kekayaan yang diperolehnya selama ini benar-benar dari harta yang halal, bukan haram.

Seorang wirausaha harus selektif dalam memilih suatu kegiatan usaha ataupun suatu pekerjaan, dan menumbuhkan etos kerja yang Islami menjadi suatu keharusan.
Tanpa itu, seorang wirausaha hanya bisa mendapat nilai materi yang secara kuantitas hanya menjanjikan kepuasan semu. Padahal nilai spiritual yang berkualitas berupa "berkah" sangat penting untuk kehidupan, bahkan lebih penting dari segala-galanya. Sesuai dengan fitrahnya, setiap manusia memerlukan harta untuk mencukupi segala kebutuhan hidupnya.

Pada saat ini Kewirausahaan (entrepreneurship) menjadi tema besar yang menarik untuk diperbincangkan, bukan saja dalam ranah ekonomi, melainkan pada setiap ranah kehidupan; sosial, kesehatan, politik, pemerintahan, bahkan pendidikan. Untuk perbincangan pada ranah terakhir, tentunya entrepreneurship akan bersinggungan dengan sub-sub tema yang antara lain berkaitan dengan pendidik, peserta didik, proses pembelajaran, dan hasil pembelajaran. Dengan kata lain, tema pendidikan adalah tema yang berkaitan dengan peran pendidik yang membantu peserta didiknya agar bakat dan potensinya berkembang optimal, sehingga lahir sumber daya manusia menjadi lebih baik.

Kewirausahaan (entrepreneurship) yang dijadikan sebagai salah satu 
kompetensi yang harus dicapai dalam Standar Kompetensi Lulusan, telah teruji mengandung nilai-nilai kebaikan yang sepatutnya dimiliki peserta didik. Nilainilai kebaikan yang terkandung yaitu mempunyai visi dan misi, kreatif dan inovatif, berani menanggung resiko, berjiwa kompetisi, mampu melihat dan menciptakan peluang, cepat tanggap dan gerak cepat, berjiwa sosial dan menjadi dermawan (Gina, 2009: 5).

Islam memang tidak memberikan penjelasan secara eksplisit terkait konsep tentang kewirausahaan (entrepreneurship) ini, namun di antara keduanya mempunyai kaitan yang cukup erat, memiliki ruh atau jiwa yang sangat dekat, meskipun bahasa teknis yang digunakan berbeda.

Islam sangat menganjurkan umatnya untuk melakukan wirausaha. Banyak ditemukan ayat atau hadits yang mendorong umat Islam untuk berwirausaha, misalnya keutamaan berdagang seperti disebutkan dalam hadits yang artinya: "Perhatikan olehmu sekalian perdagangan, dengan tangannya sendiri dan setiap jual beli yang bersih.”(HR. Al Bazzar). Dalam Al-quran menyebutkan, “..apabila shalat telah ditunaikan maka bertebaranlah kamu di muka bumi dan carilah karunia (rizki) Allah" (QS. alJumu'ah: 10).

Salah satu lembaga yang mencanangkan dan menjalankan pendidikan kewirausahaan adalah jurusan Pendidikan IPS program studi Pendidikan ekonomi UIN Suska Riau. Di jurusan ini, pendidikan kewirausahaan telah menjadi prioritas utama. Hal ini dapat dilihat pada visi jurusan yaitu; Terwujudnya lembaga yang unggul di bidang Pendidikan Ekonomi dan Kewirausahaan yang memiliki wawasan keislaman yang integratif dengan keilmuan, teknologi dan seni di Asia Tenggara Tahun 2023.

Berdasarkan penjelasan di atas, penulis tertarik untuk mengangkat permasalahan tersebut menjadi penelitian dengan judul "Peranan Pembelajaran Kewirausahaan Dalam Membentuk Karakter Yang Islami Pada Mahasiswa Pendidikan Ekonomi Uin Suska Riau”.

\section{METODE PENELITIAN}

Metode atau pendekatan yang digunakan dalam penelitian ini adalah dengan menggunakan metode kualitatif. Pendekatan kualitatif adalah suatu pendekatan penelitian yang mengungkapkan situasi social tertentu dengan mendeskripsikan kenyataan secara 
benar, dibentuk oleh kata-kata berdasarkan teknik pengumpulan data dan analisis data yang relevan ( Djam'an Satori, 2011:25).

Penelitian kualitatif tidak menggunakan istilah populasi, karena penelitian kualitatif berangkat dari kasus tertentu yang ada pada situasi social tertentu dan hasil kajiannya tidak akan diberlakukan kepopulasian, tetapi ditransferkan ketempat lain pada situasi yang memiliki kesamaan dengan situasi social pada kasus yang dipelajari. Sampel dalam penelitian kualitatif bukan dinamakan responden, tetapi sebagai narasumber atau partisipan, informan dalam penelitian (Sugiyono, 2013:298).

Penentuan informan dalam penelitian ini menggunakan teknik Purposive Sampling yaitu teknik pengambilan sampel sumber data dengan pertimbangan tertentu. Pertimbangan tertentu ini, misalnya orang tersebut yang dianggap paling tahu tentang apa yang kita harapkan, atau mungkin dia sebagai penguasa sehingga akan memudahkan peneliti menjelajahi obyek/situasi yang diteliti.

Jenis data yang akan digunakan dalam penelitian ini adalah data primer yaitu data yang langsung diiperoleh dari lapangan melaui wawancara, observasi, kuisioner. Koresponden yaitu mahasiswamahasiswa di perguruan tinggi di jurusan Pendidikan IPS program studi Pendidikan ekonomi UIN Suska Riau .

Jenis data sekunder berupa jenis data yang sudah tersedia sehingga peneliti hanya mencari dan mengumpulkan penulisan terhadap kajian/tulisan, buku, jurnal, aturan perundang-undangan dan pendapat pakar tentang masalah yang dibahas.

Keabsahan data yang digunakan peneliti untuk pengecekan data melalui dua keabsahan data yaitu:

1). Uji kredibilitas data dengan menggunakan bahan referensi.

Merupakan pendukung untuk membuktikan data yang telah ditemukan oleh peneliti, contohnya rekaman wawancara, fhoto interaksi dengan informan, dan lembaran observasi.

2). Uji kredibilitas dengan Member Check

Member Check adalah proses pengecekan data yang diperoleh peneliti kepada pemberi data. Tujuan Member Check adalah untuk mengetahuin seberapa jauh data yang diperoleh sesuai dengan apa yang diberikan pemberi data. Apa bila data yang ditemukan disepakati oleh para pemberi datanya data valid, sehingga semangkin kredibel atau dipercaya. 


\section{HASIL DAN PEMBAHASAN HASIL PENELITIAN}

Penelitian ini dilaksanakan pada bulan September 2017 terhadap mahasiswa Program Studi Pendidikan Ekonomi (PE) Fakultas Tarbiyah dan Keguruan Universitas Islam Negeri Sultan Syarif Kasim Riau (UIN Suska Riau) yang sudah mendapatkan mata kuliah Kewirausahaan yang didalamnya terdapat materi perkuliahan tentang Enterepernership. Mahasiswa Program Studi Pendidikan Ekonomi (PE) yang sudah mendapatkan mata kuliah Kewirausahaan yang di dalamnya terdapat materi tentang Enterepernership adalah mahasiswa semester 5 dan semester 7. Sehingga pada penelitian ini yang menjadi subjek penelitian adalah mahasiswa Program Studi Pendidikan Ekonomi (PE) semester 5 sebanyak 193 orang mahasiswa dan semester 7 sebanyak 45 orang mahasiswa, sehingga total subjek penelitian berjumlah 238 mahasiswa.

Data pada penelitian ini diperoleh dari angket (kuesioner) yang diberikan kepada subjek penelitian. Angket tersebut bertujuan untuk mengambil data tentang karakter Islami yang terbentuk di dalam kegiatan kewirausahaan. Seperti yang telah disebutkan sebelumnya, responde penelitian ini adalah mahasiswa dari dua semester. Mahasiswa dari dua semester tersebut dirinci berdasarkan konsentrasi, untuk semester 5 terdiri dari 6 lokal yang pembagiannya 2 lokal konsentrasi akuntansi dan 4 lokal konsentrasi manajemen yang jumlah keseluruhan mahasiswanya adalah 193. Adapun semester 7 terdiri dari 7 lokal yang pembagiannya 2 lokal akuntansi dan 5 lokal manajemen dengan total keseluruhan mahasiswa berjumlah 199 orang.

Sebagian besar mahasiswa baik itu mahasiswa semester 5 dan semester 7 memperoleh IPK di atas 3,00 sebesar 211 $(88,66 \%)$ sedangkan mahasiswa yang memperoleh IPK 2.00 sampai 3.00 sebanyak 27 orang (11,34\%). Dengan sebagian besar mahasiswa mendapatkan IPK di atas 3,00 maka sebenarnya mereka termasuk mahasiswa yang cukup pintar. Karena secara akademis dengan IPK diatas 3,00 mendapatkan predikat memuaskan.

Tabel 1. IPK Mahasiswa

\begin{tabular}{lll}
\hline IPK & $\mathrm{N}$ & Persentase (\%) \\
\hline Di atas 3.00 & 211 & 88,66 \\
$2.00-3.00$ & 27 & 11,34 \\
\hline Jumlah & 238 & 100 \\
\hline \multicolumn{2}{l}{ Sumber: Data Diolah } \\
\multicolumn{1}{c}{ Selain } & itu, persentase Mahasiswa \\
berdasarkan & jenis kelamin menujukkan \\
mahasiswa & perempuan lebih banyak
\end{tabular}


sebesar 188 mahasiswa $(79,01 \%)$ dari Mahasiswa laki-laki sebanyak 48 mahasiswa (20,99\%). Artinya, didalam program studi Pendidikan Ekonomi UIN Suska Riau pada semester 5 dan 7 di dominasi oleh mahasiswa perempuan dan dalam penelitian ini juga memperhatikan aspek genetika yang menandakan data yang diambil tidak homogen.

\section{PEMBAHASAN}

Saat ini persaingan dalam dunia kerja sangatlah ketat, penyerapan tenaga kerja dalam dunia usaha dan industri serta perekrutan pegawai negeri sangatlah terbatas dan dengan tingkat kompetensi yang tinggi. Sementara itu semakin banyaknya perusahaan melakukan Pemutusan Hubungan Kerja (PHK), sehingga membuat persaingan di antara lulusan perguruan tinggi dalam mendapatkan pekerjaan semakin ketat. Mengandalkan kepada pemerintah untuk membuka lapangan kerja baru tidaklah mungkin. Menunggu investor dari luar negeri untuk berinvestasi ke Indonesia memerlukan waktu yang cukup lama, dan mengharapkan investor dari dalam negeri dalam kondisi saat seperti ini sangatlah berat. Melihat kondisi tersebut di atas, maka dunia pendidikan harus mampu berperan aktif menyiapkan sumber daya manusia terdidik yang mampu menghadapi berbagai tantangan kehidupan lokal, nasional, regional maupun internasional yang tidak hanya menguasai teori tapi juga mampu menerapkan dalam kehidupan sosial dan yang kreatif yang mampu menciptakan lapangan pekerjaan untuk dirinya sendiri dan orang lain atau seorang wirausaha.

Sasaran dalam pembelajaran kewirausahaan adalah untuk mempersiapkan mahasiswa sebagai calon tenaga kerja yang memiliki kesiapan untuk memasuki dunia kerja. Keberadaan mahasiswa dituntut untuk memenuhi kebutuhan masyarakat, yaitu kebutuhan tenaga kerja. Sehingga mahasiswa dituntut untuk memiliki keterampilan serta sikap professional dalam bidangnya.

Dalam penelitian ini dapat disimpulkan tentang pemahaman kewirausahaan mahasiswa dapat dilihat pada tabel, sebagai berikut :

Tabel 2. Pemahaman Kewirausahaan (Entrepreneurship) Mahasiswa Pendidikan Ekonomi

\begin{tabular}{lcc}
\multicolumn{1}{c}{ Keterangan } & $\mathrm{N}$ & $\begin{array}{c}\text { Persenta } \\
\text { se (\%) }\end{array}$ \\
\hline $\begin{array}{l}\text { Tahu tentang Kewirausahaan } \\
\text { (Entrepreneurship) }\end{array}$ & 233 & 97,90 \\
$\begin{array}{l}\text { Tidak Tahu } \\
\text { Kewiausahaan } \\
\text { (Entrepreneurship) }\end{array}$ & 0 & 0.00 \\
$\begin{array}{l}\text { Ragu-ragu tentang kewirausahaan } \\
\text { (Entrepreneurship) }\end{array}$ & 5 & 2,10 \\
\hline \multicolumn{1}{c}{ Jumlah } & 238 & 100 \\
\hline Sumber: Data Diolah & &
\end{tabular}


Dari table 1 di atas dapat diketahun pemahaman kewirausahaan pada responden menunjukkan sebagian besar mahasiswa Program studi Pendidikan Ekonomi Fakultas Tarbiyah dan Keguruan UIN Suska Riau memahami konsep kewirausahaan. Hal ini di buktikan dari 238 mahasiswa $233(97,90 \%)$ tahu tentang Kewirausahaan (Entrepreneurship).

Dalam pelaksanaan kewirausahaan diketahui juga bahwa sebagian besar mahasiswa Program studi Pendidikan Ekonomi pernah melaksanakan kegiatan kewirausahaan (Entrepreneurship), hal ini dapat dilihat pada tabel, sebagai berikut:

Tabel 3. Jumlah Mahasiswa melaksanakan Kewirausahaan (Entrepreneurship)

\begin{tabular}{lll}
\hline Keterangan & N & $\begin{array}{l}\text { Persenta } \\
\text { se }(\%)\end{array}$ \\
\hline $\begin{array}{l}\text { Pernah melaksanakan kegiatan } \\
\text { Kewirausahaan } \\
\text { (Entrepreneurship). } \\
\text { Tidak Pernah melaksanakan }\end{array}$ & 232 & 97,48 \\
$\begin{array}{l}\text { kegiatan Kewirausahaan } \\
\text { (Entrepreneurship) }\end{array}$ & 2 & 0.84 \\
$\begin{array}{l}\text { Ragu-ragu pernah melaksanakan } \\
\text { kegiatan Kewirausahaan } \\
\text { (Entrepreneurship) }\end{array}$ & 4 & 1,68 \\
\hline Jumlah & 238 & 100 \\
\hline Sumber: Data Diolah & &
\end{tabular}

Dari tabel 3 diatas, sebanyak 232 mahasiswa $(97,48 \%)$, sebagian mahasiswa ragu-ragu pernah melaksanakan kegiatan kewirausahaan (Entrepreneurship) sebanyak 4 mahasiswa $(1,68 \%)$, dan sebagian kecil mahasiswa tidak pernah merasa melaksanakan kegiatan Kewirausahaan (Entrepreneurship) sebanyak 2 mahasiswa $(0,84 \%)$ dari total responden mahasiswa sebanyak 238 orang. Artinya, sebagian besar mahasiswa Program studi Pendidikan Ekonomi pernah melaksanakan kegiatan kewirausahaan.

Kegiatan kewirausahaan yang dilakukan mahasiswa Program studi Pendidikan Ekonomi merupakan implimentasi dari tugas mata Kuliah Kewirausahaan yang berada di semester 5 . Pada mata kuliah ini mereka dituntut untuk mempu membuat produk lalu memasarkannya. Hasil produk yang dihasilkan mahasiswa PE beraneka ragam mulai dari Kue Basah, Kueh Kering, Jilbab dan Kerajinan tangan (aksesoris) lainnya.

Strategi pemasaran yang dilakukan oleh mahasiswa Program Studi Pendidikan Ekonomi adalah dengan menjual langsung baik dari teman ke teman maupun melalui media sosial. Selain itu, sebagian mahasiswa menitipkan barang yang di buatnya pada labor Kewirausahaan milik prodi sendiri, toko dan warung.

Kegiatan kewirausahaan ini Prasetyo (2009) mengemukakan bahwa kewirausahaan pada hakekatnya adalah sifat, ciri dan watak seseorang yang memiliki kemauan dalam mewujudkan gagasan inovatif ke dalam dunia nyata secara kreatif. Istilah kewirausahaan 
berasal dari terjemahan "Entrepreneurship", dapat diartikan sebagai "the backbone of economy", yang adalah syaraf pusat perekonomian atau pengendali perekonomian suatu bangsa. Secara epistimologi, kewirausahaan merupakan suatu nilai yang diperlukan untuk memulai suatu usaha atau suatu proses dalam mengerjakan sesuatu yang baru dan berbeda. Kewirausahaan merupakan penerapan kreativitas dan keinovasian untuk memecahkan permasalahan dan upaya untuk memanfaatkan peluang yang dihadapi sehari hari.

Kewirausahaan merupakan gabungan dari kreativitas, keinovasian dan keberanian menghadapi resiko yang dilakukan dengan cara kerja keras untuk membentuk dan memelihara usaha baru. Pandangan ini sesuai dengan pandangan dengan mahasiswa program studi Pendidikan Ekonomi yang mengatakan dengan mempelajari kewirausahaan dan mempraktekkkanya dapat membuat diri menjadi kreatif dan inovatif. Keratif disini mahasiswa manpu menciptakan produk baru sedangkan inovatif di sini mereka manpu memasarkan produk mereka dengan cara dan strategi beda yang lainnya.

Hal ini sesuai dengan hasil Kuesioner penelitian, yang dapat dilihat pada tabel, sebagai berikut:

Tabel 4. Kewirausahaan (Entrepreneurship) dapat membuat kreatif dan inovatif

\begin{tabular}{lcc}
\hline \multicolumn{1}{c}{ Keterangan } & N & $\begin{array}{c}\text { Persenta } \\
\text { se }\end{array}$ \\
\hline $\begin{array}{l}\text { Membuat kita kreatif dan inovatif } \\
\text { Ragu-ragu dapat Membuat kita } \\
\text { kreatif dan inovatif }\end{array}$ & 217 & 91,18 \\
$\begin{array}{l}\text { Tidak Membuat kita kreatif dan } \\
\text { inovatif }\end{array}$ & 8 & 5,46 \\
\hline$\quad$ Jumlah & 238 & 100 \\
\hline
\end{tabular}

Sumber: Data Diolah

Dari tabel 4 di atas, sebagian besar mahasiswa mengatakan Kewirausahaan (Entrepreneurship) dapat membuat kreatif dan inovatif sebanyak 217 mahasiswa $(91,18 \%)$, sebagian mahasiswa lagi mengatakan ragu-ragu Kewirausahaan (Entrepreneurship) dapat Membuat kita kreatif dan inovatif sebanyak 13 mahasiswa $(5,46 \%)$ dan sebagian kecil mahasiswa mengatakan Kewirausahaan (Entrepreneurship) tidak dapat Membuat kita kreatif dan inovatif sebanyak 8 mahasiswa $(3,36 \%)$ dari total responden mahasiswa sebanyak 238 orang. Artinya, bahwa dengan melakukan kegiatan Kewirausahaan (Entrepreneurship) dapat membuat mahasiswa itu menjadi kreatif dan inovatif.

Pemahaman mahasiswa program studi Pendidikan Ekonomi tentang Islam menganjurkan kewirausahaan dapat diketahui dari kuesioner yang di isi 
mahasiswa dalam penelitian ini.

Tabel 5. Pengetahuan Mahasiswa tentang Islam meganjurkan untuk berwirausahaan (Entrepreneurship)

\begin{tabular}{|c|c|c|c|}
\hline Keterangan & & $\mathrm{N}$ & $\begin{array}{c}\text { Persenta } \\
\text { se }\end{array}$ \\
\hline $\begin{array}{l}\text { Mengetahui tentang } \\
\text { meganjurkan } \\
\text { berwirausahaan } \\
\text { (Entrepreneurship) }\end{array}$ & $\begin{array}{l}\text { Islam } \\
\text { untuk }\end{array}$ & 177 & 74,37 \\
\hline $\begin{array}{l}\text { Tidak mengetahui tentang } \\
\text { meganjurkan } \\
\text { berwirausahaan } \\
\text { (Entrepreneurship) }\end{array}$ & $\begin{array}{l}\text { Islam } \\
\text { untuk }\end{array}$ & 27 & 11,34 \\
\hline $\begin{array}{l}\text { Ragu-ragu tentang } \\
\text { meganjurkan } \\
\text { berwirausahaan } \\
\text { (Entrepreneurship) }\end{array}$ & $\begin{array}{l}\text { Islam } \\
\text { untuk }\end{array}$ & 34 & 14,29 \\
\hline Jumlah & & 238 & 100 \\
\hline
\end{tabular}

Sumber: Data Diolah

Dari hasil yang diapatkan bahwa sebagian besar mahasiswa mengatakan mengetahui tentang Islam meganjurkan untuk berwirausahaan (Entrepreneurship) sebanyak 177 mahasiswa (74,37\%). Sebagian mahasiswa mengatakan tidak mengetahui tentang Islam meganjurkan untuk berwirausahaan (Entrepreneurship) sebanyak 27 mahasiswa (11,34\%), dan sebagian lagi mahasiswa mengatakan raguragu tentang Islam meganjurkan untuk berwirausahaan (Entrepreneurship) sebanyak 34 mahasiswa $(14,29 \%)$ dari responden mahasiswa 238 orang. Artinya sebagian besar mahasiswa mengetahui bahwa Islam menganjurkan berwirausaha.

Selain dianjurkan dalam Islam untuk berwirausaha, terdapat beberapa karakter yang Islami terbentuk ketika melakukan kegiatan kewirausahaan. Hal ini di buktikan dengan kuesioner yang diisi mahasiswa yang mana sebagian besar mahasiswa mengatakan banyak karakter terbentuk dalam kewirausahaan (Entrepreneurship) sebanyak 213 mahasiswa $(79,50 \%)$, sebagian mahasiswa mengatakan tidak banyak karakter bisa terbentuk dalam kewirausahaan (Entrepreneurship) sebanyak 8 mahasiswa $(3,36 \%)$, dan sebagian mahasiswa mengatakan ragu-ragu dapat membentuk banyak karakter dalam kewirausahaan (Entrepreneurship) sebanyak 17 mahasiswa $(17,14 \%)$ dari responden mahasiswa 238 orang. Dari hasil tersebut dapat disimpulkan bahwa memang terdapat karakter Islami yang terbetuk seperti bekerja keras, adil, amanah, bertanggung jawab dan mandiri.

Dilihat dari pembentukan karakter kerja keras di dalam kewirausahaan telah ada, hal ini di buktikan melalui kuesioner yang diberikan kepada mahasiswa program studi Pendidikan Ekonomi dan di peroleh sebanyak 204 mahasiswa $(85,72 \%)$ sudah terbentuk, sisa lain nya tidak terbentuk sebanyak 9 mahasiswa $(3,78 \%)$, dan yang menjawab ragu-ragu sebanyak 25 mahasiswa $(10,50 \%)$ dari responden mahasiswa 238 orang. Hasil ini, dapat disimpulkan bahwa kewirausahaan 
membentuk karakter kerja keras. Kemudian di dalam Islam karekter kerja keras di sebutkan didalam Al qur'an yang berbunyi " Dan Katakanlah: "Bekerjalah kamu, Maka Allah dan Rasul-Nya serta orangorang mukmin akan melihat pekerjaanmu itu, dan kamu akan dikembalikan kepada (Allah) yang mengetahui akan yang ghaib dan yang nyata, lalu diberitakan-Nya kepada kamu apa yang telah kamu kerjakan (Q.S At-Taubah Ayat 105).

Dilihat dari pembentukan karakter Adil ('adilun) di dalam kewirausahaan telah ada, hal ini di buktikan melalui Kuesioner kepada mahasiswa program studi Pendidikan Ekonomi dan di peroleh sebanyak 191 mahasiswa $(80,25 \%)$ sudah terbentuk, sisa lain nya tidak terbentuk sebanyak 16 mahasiswa $(6,72 \%)$, dan yang menjawab ragu-ragu sebanyak 31 mahasiswa $(13,03 \%)$ dari responden mahasiswa 238 orang. Hasil ini dapat disimpulkan bahwa kewirausahaan membentuk karakter Adil ('adilun). Kemudian di dalam Islam karekter Adil ('adilun) di sebutkan didalam Al qur'an yang berbunyi "Maka putuskanlah (perkara itu) diantara mereka dengan adil, Sesungguhnya Allah menyukai orangorang yang adil"(Q.S.Al-Maidah 5:42).

Dilihat pembentukan karakter
Percaya (amanah) di dalam kewirausahaan telah ada, hal ini di buktikan melalui Kuesioner kepada mahasiswa program studi Pendidikan Ekonomi dan di peroleh sebanyak 200 mahasiswa (84,04\%) sudah terbentuk. Sisa lain nya tidak terbentuk sebanyak 11 mahasiswa (4,62\%), dan yang menjawab ragu-ragu sebanyak 27 mahasiswa $(11,34 \%)$ dari responden mahasiswa 238 orang. Hasil ini dapat disimpulkan bahwa kewirausahaan membentuk karakter Percaya (amanah). Kemudian di dalam Islam karekter Percaya (amanah) di sebutkan didalam Al qur'an yang berbunyi "Sesungguhnya Allah menyuruh kamu menyampaikan amanat kepada yang berhak menerimanya". (Q.S.An-Nisa 4:58).

Selanjutnya pembentukan karakter Jujur di dalam kewirausahaan telah ada, hal ini di buktikan melalui Kuesioner kepada mahasiswa program studi Pendidikan Ekonomi dan di peroleh sebanyak 175 mahasiswa $(73,53 \%)$ sudah terbentuk. Sisa lainnya tidak terbentuk sebanyak 27 mahasiswa (11,34\%), dan yang menjawab ragu-ragu sebanyak 36 mahasiswa $(15,13 \%)$ dari responden mahasiswa 238 orang. Hasil ini dapat disimpulkan bahwa kewirausahaan membentuk karakter Jujur. Kemudian di dalam Islam karekter Jujur di 
sebutkan didalam Al qur'an yang berbunyi “...oleh karena itu, hendaklah mereka bertakwa kepada Allah SWT dan hendaklah mereka mengucapkan perkataan yang benar" (QS. An-Nisa 4:9).

Kemudian pembentukan karakter Tanggung jawab di dalam kewirausahaan telah ada, hal ini di buktikan melalui Kuesioner kepada mahasiswa program studi Pendidikan Ekonomi dan di peroleh sebanyak 176 mahasiswa $(73,95 \%)$ sudah terbentuk. Sisa lain nya tidak terbentuk sebanyak 33 mahasiswa $(13,87 \%)$, dan yang menjawab ragu-ragu sebanyak 29 mahasiswa $(12,18 \%)$ dari responden mahasiswa 238 orang. Hasil ini dapat disimpulkan bahwa kewirausahaan membentuk karakter Tanggung jawab. Kemudian di dalam Islam karekter Tanggung jawab di sebutkan di dalam sabda Nabi Shalallohu Alaihi wa Salam "setiap kalian adalah pemimpin, dan setiap kalian akan dimintai pertanggungjawaban atas apa yang kalian pimpin” (HR. Muslim).

Selanjutnya pembentukan karakter Mandiri di dalam kewirausahaan telah ada, hal ini di buktikan melalui Kuesioner kepada mahasiswa program studi Pendidikan Ekonomi dan di peroleh sebanyak 162 mahasiswa $(68,06 \%)$ sudah terbentuk. Sisa lain nya tidak terbentuk sebanyak 44 mahasiswa $(18,49 \%)$, dan yang menjawab ragu-ragu sebanyak 32 mahasiswa $(13,45 \%)$ dari responden mahasiswa 238 orang. Hasil ini dapat disimpulkan bahwa kewirausahaan membentuk karakter Mandiri. Kemudian di dalam Islam karakter Mandiri di sebutkan didalam Al qur'an “Kami tiada membebani seseorang melainkan menurut kesanggupannya, dan pada sisi Kami ada suatu kitab yang membicarakan kebenaran, dan mereka tidak dianiaya" ( Q.S AlMukminun ayat 62).

\section{SIMPULAN DAN SARAN}

\section{Simpulan}

Dari hasil penelitian dan pembahasan di atas dapat disimpulkan bahwa peranan pembelajaran kewirausahaan dalam membentuk karakter yang islami pada mahasiswa pendidikan ekonomi UIN Suska Riau adalah sebagai berikut:

1. Pemahaman Mahasiswa pendidkan Ekonomi Tentang Kewirausahaan

a. sebagian besar mahasiswa Program studi Pendidikan Ekonomi Fakultas Tarbiyah dan Keguruan UIN Suska Riau memahami konsep 
kewirausahaan. Hal ini di buktikan dari 238 mahasiswa $233 \quad(97,90 \%)$ diantaranya tahu tentang

Kewirausahaan

(Entrepreneurship);

b. Sebagian besar mahasiswa Program studi Pendidikan Ekonomi pernah melaksanakan kegiatan kewirausahaan (Entrepreneurship) sebanyak 232 mahasiswa $(97,48 \%)$ dari responden mahasiswa 238 orang;

c. sebagian besar mahasiswa mengatakan mengetahui tentang Islam meganjurkan untuk berwirausahaan (Entrepreneurship) sebanyak 177 mahasiswa $(74,37 \%)$ dari responden mahasiswa 238 orang;

2. Karakter Islami dalam kewirausahaan (Entrepreneurship) yang Terbentuk

a. Diperoleh sebanyak 204 mahasiswa $(85,72 \%)$ sudah terbentuk karakter kerja keras dari responden mahasiswa 238 orang; b. Diperoleh sebanyak 191 mahasiswa $(80,25 \%)$ sudah terbentuk karakter Adil ('adilun) dari responden mahasiswa 238 orang;

c. Diperoleh sebanyak 200 mahasiswa $(84,04 \%)$ sudah terbentuk karakter Percaya (amanah) dari responden mahasiswa 238 orang;

d. Diperoleh sebanyak 175 mahasiswa $(73,53 \%)$ sudah terbentuk karakter Jujur dari responden mahasiswa 238 orang;

e. Diperoleh sebanyak 176 mahasiswa $(73,95 \%)$ sudah terbentuk karakter Tanggung Jawab dari responden mahasiswa 238 orang;

f. Diperoleh sebanyak 162 mahasiswa $(68,06 \%)$ sudah terbentuk Karakter Mandiri dari responden mahasiswa 238 orang.

\section{Saran}

Berdasarkan hasil penelitian dan kesimpulan yang telah dikemukakan diatas, maka dapat diberikan saran: 
1. Mahasiswa Pendidikan Ekonomi diberikan luang untuk membuka kewirausahan, selain di Kampus dengan bimbingan dari fihak Prodi dan Falkutas.

2. Mahasiswa Pendidikan Ekonomi diberikan Pelatihan yang rutin pada ekonomi kreatif.

3. Pihak Prodi dan Falkultas melakukan kerjasama dengan pemeritahan dan Swasta.

4. Setiap pertemuan

Perkulihan, dosen Pendidikan Ekonomi memberikan motivasi untuk dunia usaha selain pada dunia pendidikan.

\section{DAFTAR PUSTAKA}

Abu Ahmadi dan Nur Uhbiyati. 2001. Ilmu Pendidikan. Jakarta: Rineka Cipta.

Abdullah, Amin, dkk. 2003. Menyatukan Kembali Ilmu Agama dan Ilmu Umum. Yogyakarta: Suka Press.

Alma, Buchari. 2009. Kewirausahaan. Bandung. ALFABETA
Amril M. 2005. Etika dan Pendidikan. Pekanbaru: LSFK2P.

Anas Sudijono. 2006. Pengantar Statistik Pendidikan. Jakarta: Raja Grafindo Persada.

Farid. 2017. Kewirausahaan Syariah. Depok. Kencana

Guntur Setiawan. 2000. Implementasi Dalam Birokrasi Pembangunan. Jakarta: Bandung: Alfabeta.

Hartono. 2011. Metodologi Penelitian. Pekanbaru: Zanafa Publishing.

Hendro. 2011. Dasar-dasar Kewirausahaan. Jakarta: Erlangga

Hisrich, Robert. D. 2008. Enterpreneurship (terjemahan). Jakarta. Salemba Empat

http://pusdatinaker.balitfo.depnakertrans.go

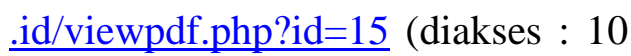
maret 2017).

Longenecker, g, Justin. 2001. Kewirausahaan: manajemen usaha kecil. Jakarta: Salemba empat

Kasmir. 2010. Kewirausahaan. Jakarta: PT Raja Gravindo Persada

Koentjaraningrat. 2000. Kebudayaan Mentalitas dan Pembangunan. Jakarta. Grmedia Pustaka Utama Kementerian Pendidikan Nasional. 2010. Pengembangan Pendidikan Budaya 
Dan Karakter Bangsa. Jakarta:

Kemendiknas.

Kewirausahaan Teori dan Praktek,

Penerbit PPM, 2003. Tim Pusat

Kurikulum Pengembangan

Pendidikan Karakter, 2010. Panduan

Pendidikan Karakter di Sekolah

Menengah Pertama, Jakarta:

Direktorat Pembinaan Sekolah

Menengah Pertama Direktorat

Jenderal Mandikdasmen

Kemendiknas RI.

Mulyasa. 2012. Manajemen Pendidikan

Karakter.Jakarta: Bumi Aksara.

Nana Sudjana. 2009. Dasar-dasar Proses

Belajar Mengajar. Bandung: Sinar

Baru Algesindo.

Rif'at Syauqi Nawawi. 2011. Kepribadian

Qur'ani. Jakarta: AMZAH.

Santosa, Gina, 2009. Pengembangan

Kurikulum Sejarah Berbasis Skill

dan Entrepreneurship untuk

Peningkatan Kompetensi Lulusan,

Makalah Lokakarya Nasional: PPS

Undip Semarang.

Suparman, Suhamidja. 2000. Membina

Mental Wiraswasta. Jakarta: Gunung

Jati

Yunus, Muhammad. Islam dan

Kewirausahaan Inovatif (Malang :

UIN Malang Press, 2008). 